\title{
Subacute sclerosing panencephalitis: measles encephalitis of temperate evolution?
}

\author{
A. D. DAYAN \\ Department of Neuropathology, Hospital for Sick Children, \\ Great Ormond Street, London, W.C.1
}

\begin{abstract}
Summary
Subacute sclerosing panencephalitis is a rare disorder of late childhood and early adolescence Affected patients usually show behavioural and intellectual disturbance and involuntary movements before dying in coma after about 12 months. At some stage most have characteristic electroencephalographic abnormalities. Pathologically, changes in the brain are those of subacute encephalitis with a variable gliosis of the white matter, and sometimes intranuclear inclusion bodies in neurones and glial cells.

Recent studies in many patients have shown high levels of circulating anti-measles antibodies, measles antigen in cells in the brain, and sometimes, myxovirus filaments in cells there. These findings suggest that SSPE may be a slow measles virus infection of the nervous system. Possible explanations for the slow evolution of the encephalitis include disordered immune mechanisms and intracellular persistence of virus in a defective phase.
\end{abstract}

\section{Introduction}

Amongst viral encephalitides an unusual type is subacute sclerosing panencephalitis (SSPE, Greenfield, 1950). It is of particular interest, however, as one of the rare examples in man of a slowly evolving infection due to a known agent-measles virus (Symposium, 1968). Knowledge of SSPE may further our understanding of other chronic disorders of the nervous system, for which an infective aetiology (such as a slow virus) has been suggested, e.g. motorneurone disease and multiple sclerosis.

SSPE was first described in terms of its pathology and only later were its clinical features determined. Subsequently, characteristic electroencephalographic abnormalities have been recognized, and very recently its viral aetiology has been illuminated by immunological and electron microscope techniques.

\section{Clinical features}

SSPE is typically a disease of late childhood and adolescence, although a few cases have been recorded earlier in life and in middle age (Lorand, Nagy \& Tariska, 1962; Canal \& Torck, 1964). It occurs in males twice as often as in females. Insufficient numbers of cases have been reported for epidemiological studies, but SSPE seems to occur in many countries, and it is uncertain whether the relatively large number of patients diagnosed in Eastern Europe (Symposium, 1961; Lorand et al., 1962) truly represents a greater incidence of SSPE than in Western Europe and the U.S.A., or a heightened interest in the disease.

The progress of SSPE may conveniently be divided into three stages (Foley \& Williams, 1953)—onset with prominent behavioural changes, intellectual deterioration and petit mal and akinetic attacks; middle stage of complex involuntary movements akin to myoclonic jerks (Metz, Gregoriou \& Sandifer, 1964), other extrapyramidal signs and increasing dementia and lack of response to external stimuli; and a third stage of profound dementia, signs of decortication and diminution of abnormal movements. It usually ends in death of the patient 6-12 months after onset of the disease, although longer survival and even apparent arrest may occur (Malamud, Haymaker \& Pinkerton, 1950; Cobb \& Morgan Hughes, 1968).

\section{Electroencephalography}

Characteristic changes in the EEG of diagnostic value were described by Radermecker (1949), and have been illustrated by Foley \& Williams (1953) and Cobb (1966). Apart from generalized disturbances of rhythm, at some stage of the disease there are almost unique periodic complexes (Fig. 1). These

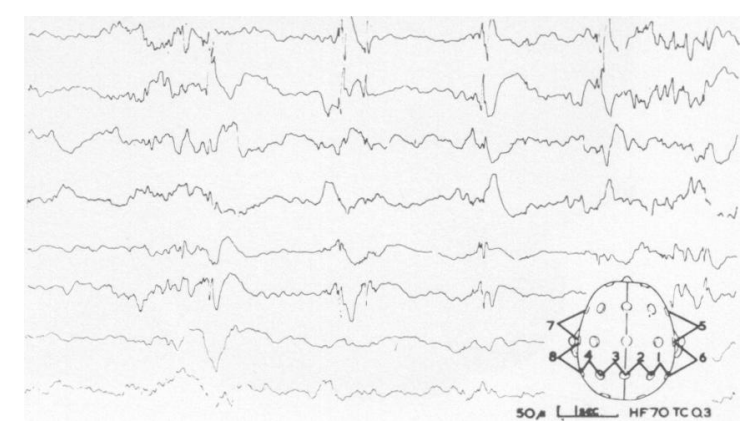

FIG. 1. EEG from a case of SSPE showing periodic complexes. 
may coincide with jerky movements of the body and limbs, or with episodes of inhibition of muscular activity (Pampiglione, 1964a, b).

\section{Laboratory investigations}

Until recent virological studies the only test of diagnostic value was the finding of a first zone 'paretic' Lange curve in the cerebrospinal fluid, due to the presence of abnormally large amounts of $\gamma$-globulin, IgG (Cutler et al., 1967; Kolar, 1968).

\section{Pathology}

The three main patterns of brain damage in SSPE at first were described independently as distinct diseases - inclusion - body encephalitis (Dawson, 1933), nodular panencephalitis (Pette \& Döring, 1939), and, subacute sclerosing leuco-encephalitis (van Bogaert, 1945) - their nosological identification only being achieved later (Greenfield, 1950; van Bogaert, 1958).

The main features of the pathology are of a subacute encephalitis affecting grey and white matter to a variable degree and accompanied by diffuse, sometimes marked gliosis. Affected brains may show generalized atrophy in the later stages of the disease when the damaged white matter appears unusually firm and greyish in colour. Histologically, the worst affected parts of the cerebral cortex are usually the parietal and temporal lobes (Osetowska, 1961), where there is destruction and degeneration of neurones, accumulation of macrophages and chronic inflammatory cells and prominent perivascular cuffing by plasma cells, lymphocytes and other mononuclear cells (Fig. 2). In affected areas there is usually marked gliosis (Fig. 3). Basal ganglia and the brain stem may also be affected (Guazzi, 1961; Osetowska \& Torck, 1962). To a variable extent white matter of the cerebral hemispheres and brainstem may show a similar pathological process with diffuse destruction of myelinated fibres, often true

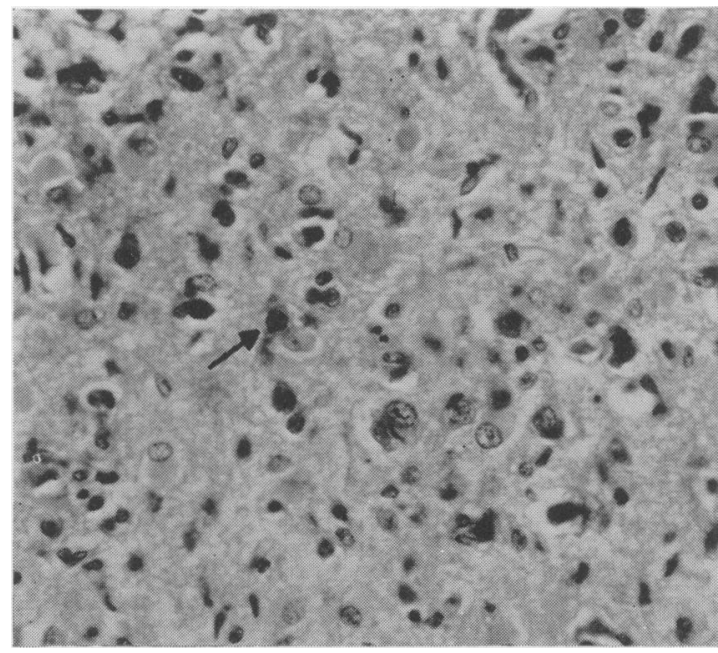

Fig. 2. Loss of neurones, gliosis and accumulation of macrophages and other chronic inflammatory cells in cerebral cortex. Note cell with intranuclear inclusion body (arrowed). H \& E, $\times 250$.

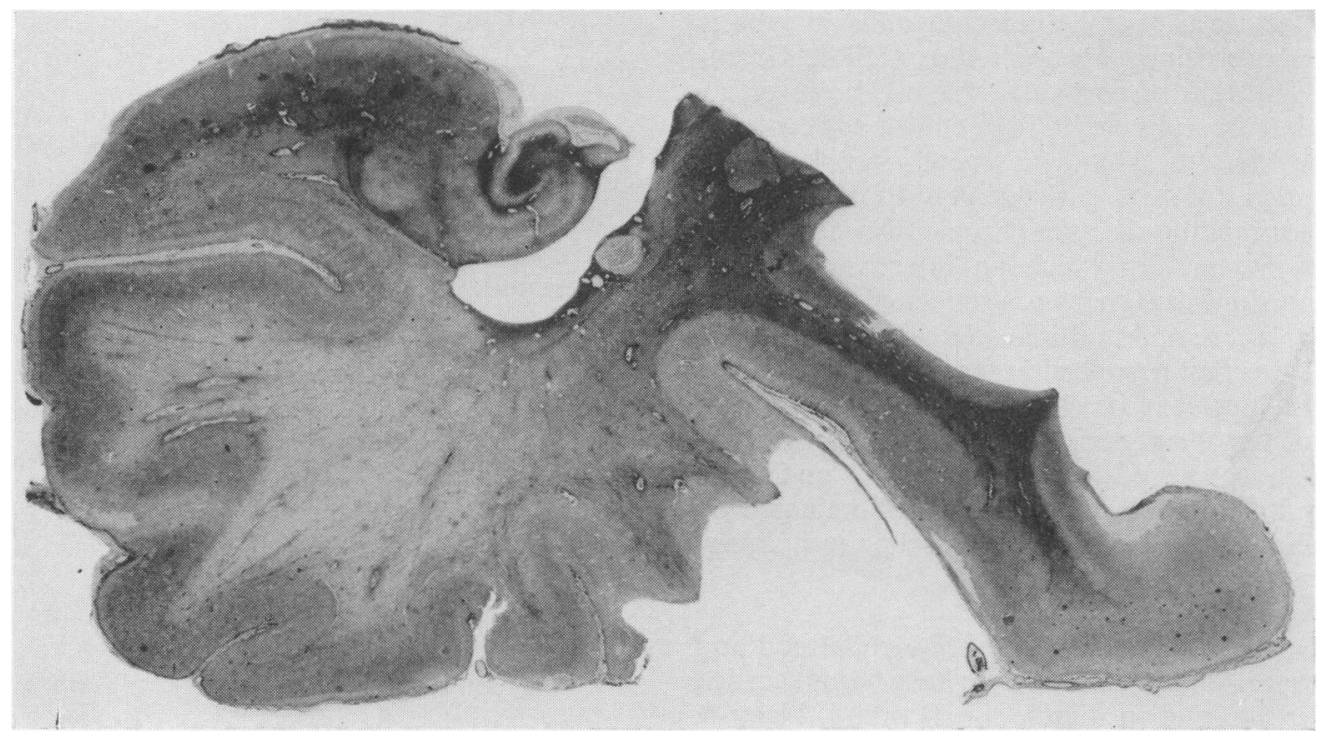

FIG. 3. Diffuse gliosis of white matter and cortex of temporal lobe. Holzer, $\times 3$. 
demyelination rather than a Wallerian-like degeneration with concurrent disappearance of axis cylinders. There may also be some perivascular cuffing by inflammatory cells (Fig. 4). Neurones and long

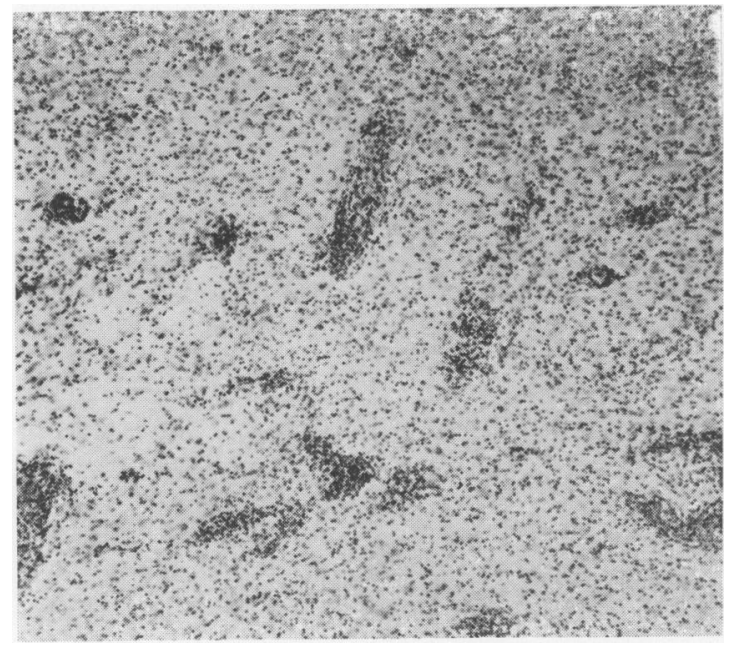

Fig. 4. Marked perivascular cuffing by inflammatory cells in centrum semiovale. Nissl, $\times 20$.

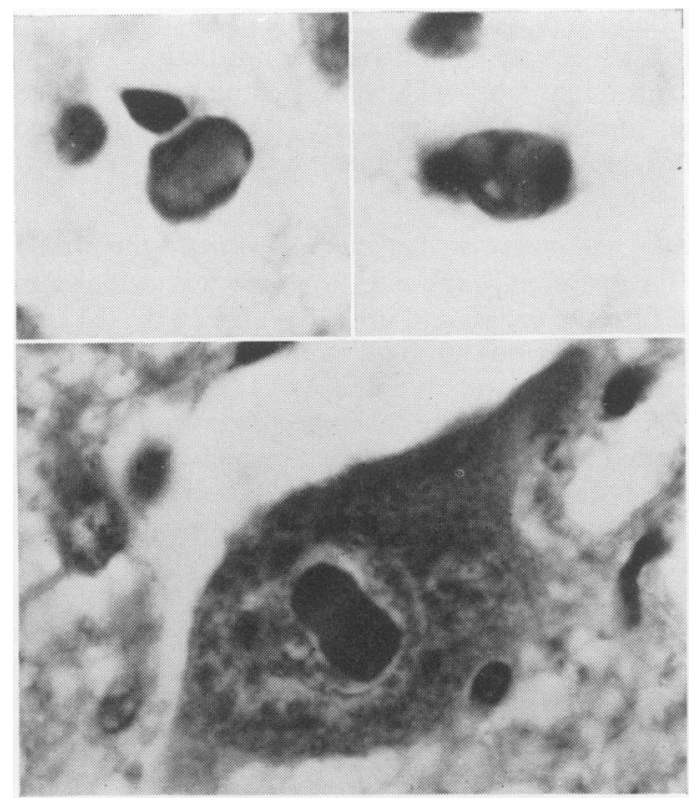

FIG. 5. Composite views of intranuclear inclusion bodies in neurones and glial cells. H \& E, $\times 950$.

tracts in the spinal cord may be affected too. There are no histological features of measles infection in systemic viscera.

\section{Inclusion bodies}

Cases of SSPE of short duration may contain Cowdry Type A intranuclear inclusion bodies (Fig. 5) in neurones and macroglial cells in both grey and white matter. Flocculated eosinophilic cytoplasmic inclusion bodies are found more rarely, and then only in neurones which also contain intranuclear inclusions. Three stages of development of inclusion bodies have been described by Herndon \& Rubinstein (1968). The commonest type is homogeneous, eosinophilic and phloxinophilic and either has a distinct edge or may completely fill the nucleus of an affected cell. Histochemical reactions suggest that the inclusions usually contain protein and ribonucleic acid.

The frequency with which inclusion bodies have been found in SSPE is very variable. It seems likely that they disappear during the later stages of the illness and they may be absent from cases in which sclerosis of the white matter is the main pathological finding. The number of inclusions varies greatly in different parts of the same brain, so, although their presence supports the diagnosis of SSPE it is not essential for it.

\section{Recent progress}

The typical features of SSPE, clinically and pathologically, had been collated by the late 1950s (Symposium, 1961). Influenced by the striking inclusion bodies, most pathological studies since then have employed divers techniques in attempts to discover the virus presumed to cause the disease.

An early report by Pelc, Périer \& Quersin-Thiry (1958) claimed to have produced the disease in chimpanzees by intra-cerebral inoculation of fresh brain from a case of SSPE. An atypical encephalitis occurred in one animal but the disease could not be transmitted and no virus was identified. Echoing some work of Weston Hurst who grew herpes simplex virus in the brain of one case of SSPE (Foley \& Williams, 1953), but who himself regarded the isolation as coincidental, Sherman, Davis \& Haymaker (1961) reported positive staining of the brain of one case by fluorescent anti-herpes simplex antibody. They too were uncertain of the significance of the observation and others since have failed to repeat it.

More significant advances have come from the use of electron microscopy and immunological techniques.

\section{Electron microscopy}

In 1965 Bouteille and his colleagues examined the brain of a case of SSPE by electron microscopy and found virus-like tubules in it. Although there have since been some failures to find these structures in both autopsy and biopsy samples of brain, many subsequent reports have shown similar virus-like 
tubules or filaments, about $180 \AA$ diameter and sometimes surrounded by an outer coat (Tellez Nagel \& Harter, 1966; Dayan et al., 1967; Périer, Vanderhaeghen \& Pelc, 1967; Herndon \& Rubinstein, 1968). Cases in which these structures have not been found have usually been those in which inclusion bodies could not be found on light microscopy. The tubules (Fig. 6) have a compound helical struc-

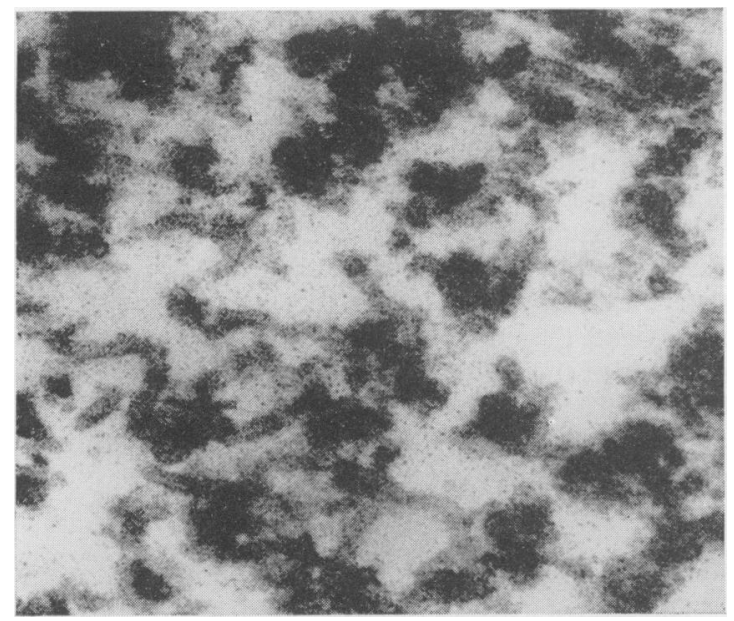

Fig. 6. Virus-like filaments, probably measles virus, in electron micrograph of cerebral cortex of a case of SSPE. $\times 100,000$.

ture, clearly shown in negatively stained preparations (J Almeida, personal communication 1967), and on morphological grounds appear to be a paramyxovirus of the measles-canine distemper group (Waterson \& Almeida, 1966).

\section{Immunological investigations}

Classical techniques of antibody assay and fluorescence microscopy for detection of specific antigens were applied to serum, CSF and brain of three cases of SSPE by Connolly et al. (1967). They found abnormally high titres of anti-measles antibody in serum and CSF from all their patients, and were able to show specific measles antigen in neurones and glial cells in cerebral biopsies. Their work was extended by Dayan et al. (1967), Legg (1967), Freeman et al. (1967), Lennette, Magoffin \& Freeman (1968) and others (summarized in Symposium, 1968). Almost consistent findings have been of very high levels of specific anti-measles antibody in serum and CSF, and of measles virus antigen in parenchymal cells in the central nervous system. The actual titres of antibody have often been higher than the values expected after a clinical attack of measles, suggesting chronicity of exposure to antigen (Adels et al., 1968). Legg reported several cases whose anti-measles antibody titres were in the normal range, but as his cases were drawn from a very heterogeneous population, and as some patients were only examined once, it is difficult to decide the significance of these observations.

Most of the large amounts of $\gamma$-globulin in the CSF are produced within the nervous system (Kolar, 1968; Cutler et al., 1967), probably by the many plasma cells and chronic inflammatory cells with pyroninophilic cytoplasm found in the parenchyma of the brain and the perivascular infiltrates.

In view of the small number of reported cases of SSPE (fewer than forty) in which we have morphological and immunological evidence of measles virus infection it should not be assumed yet that the disease is truly a single nosological entity due only to one virus. The convenience of such simplicity must await examination of many more cases. It has been challenged by Katz et al. (1968) who claim to have transmitted SSPE to ferrets and were unable to detect any evidence of measles virus in affected animals. The significance of their finding is uncertain because of the preliminary nature of their report (Lancet, 1968).

\section{Aetiology of SSPE}

Patients suffering from SSPE appear to have measles virus tubules inside cells in the nervous system, and to be producing large amounts of globulin systematically and in the brain, at least some of which is specific anti-measles antibody.

Although two of Koch's postulates have been met more or less adequately, there are still major unexplained features about the disease.

\section{Entry and persistence of measles virus in the brain}

Unanswered, basic questions are when does virus get into the brain, and how it is able to persist there for long periods despite high levels of circulating antibody?

No unusual features have been reported about the original attacks of measles from which SSPE patients have suffered, but clinical records have been scant of so mundane a childhood illness occurring so long before the onset of SSPE.

There is evidence from EEG and histological studies of a very mild acute encephalitis during most clinical and sub-clinical attacks of measles (Gibbs et al., 1959; Pampiglione, 1964a, b; Adams, Baird \& Filloy, 1966) which may be due to direct invasion of the brain by virus. There is also experimental and some little clinical evidence that measles can cause a very chronic infection of cells (Enders Ruckle, 1965; Rustigian, 1966) despite the presence of specific antibodies. It is possible that measles virus is always harboured for a time in the brain after an attack of morbilli. Such behaviour may occur when the virus is in a defective form (Frazer, 1967) in which only 
some of its complex structural subunits are assembled and passed from cell to cell. Most published electron micrographs have shown incomplete forms, and only Herndon \& Rubinstein (1968) have illustrated morphologically complete virus. However, ultrastructural studies alone cannot prove the presence of mature or defective phases of the virus which have more of the nature of functional states, and should be distinguished in terms of their effects on living systems. Unfortunately, we know little about the conditions under which myxoviruses enter a defective phase, but it seems possible that this happens in the brains of patients with SSPE, and such behaviour can help to explain the lengthy intracellular persistence of virus.

Almost all patients who have measles recover without getting SSPE and there is a latent period of several years between clinical measles and the clinical onset of the encephalitis. It is possible, therefore, that SSPE is due to a fresh infection, perhaps by another strain of measles, and not to reactivation of the original virus. In both cases, the latency and persistence of infection may be due to the intracellular localization of virus where it is inaccessible to antibodies, and also to the relative impermeability of the blood-brain barrier to systemic $\gamma$-globulin (Cutler et al., 1967). These mechanisms may also be responsible for the apparent restriction of virus to the central nervous system in SSPE. An hypothetical role for live measles virus vaccine as a cause of SSPE has been discussed, but only one possible vaccine-associated case has been reported (Schneck, 1968).

\section{Pathogenesis of SSPE: viral damage or immunological attack?}

The pathological features of diffuse destruction and marked inflammatory and antibody response to a disorder of temperate evolution raise unsolved problems of the pathogenesis of tissue damage in SSPE. It should not be assumed that the classical process of direct attack on cells by virus, and their subsequent destruction is the sole cause of tissue damage. Although this process may well be important, the striking immunological response in SSPE has led to the suggestion that sensitized cells and anti-brain antibodies aroused by the disease may in part be responsible for the damage (Kolar, 1968; Zeman \& Kolar, 1968) as may the effects of other antigen-antibody complexes formed or deposited in the brain. As virus survives for a long period inside cells of the nervous system and may alter them antigenically or expose normally concealed antigens, it has also been suggested that immunological damage may occur by mechanisms of the type proposed by Webb \& Smith (1966). Very rarely there have been cases of SSPE in whom a clinical attack of measles, including a skin rash, has occurred during the course of the illness $(\mathrm{H}$. Urich, personal communication 1967). It is difficult even to speculate profitably about the pathological reactions in such cases.

A further possible mechanism for disordered functioning of the brain is a virus-induced alteration of metabolic pathways short of cell death. Viral infection may result in the appearance and persistence of perverted metabolism in cells, and it is feasible that affected neurones and glial cells may function in an abnormal, incomplete or even intermittent fashion if a subtle chemical lesion were to affect, for example, neurotransmitter production or release. This hypothesis has recently received some possible support from the finding of abnormal patterns of ganglioside synthesis in the brains of some SSPE cases (Ledeen, Salsman \& Cabrara, 1968; Dayan \& Cumings, 1969). It may apply to other slow virus diseases too.

\section{Investigation of a case of SSPE}

Certain tests form part of the diagnostic process which the patient will probably have undergone already, i.e. apart from the clinical history and examination, it is likely that CSF will already have been examined for cells, protein and sugar content, and that an EEG will have been recorded. Information gained from these and other tests would lead a clinician to suggest the diagnosis of SSPE. There are two further lines of investigation which should be followed as far as clinical judgment and laboratory resources permit.

\section{Proof of diagnosis}

Clinical and EEG features of SSPE have a reasonably characteristic natural history over a period of several months, so follow-up studies are essential. The concentration of IgG in CSF (or, at least Lange curves) and serum should be measured repeatedly. Antibody titres against the divers antigens of measles virus should also be measured repeatedly in CSF and serum and the levels compared with other antibodies to test for local production of antibody in the CNS. However, any particular level of antibody, high or low, cannot prove or disprove the diagnosis because the longitudinal studies of Connolly et al. (1967), Legg (1967) and Adels et al. (1968) have shown that the actual titres recorded may be high or low, and may move either up or down, depending perhaps on the stage of the disease and its clinical course. Antibodies against other viruses should also be measured, particularly members of the myxovirus group, and others, e.g. arboviruses, which can cause a chronic encephalitis.

Whether to do a brain biopsy for diagnostic purposes is a complex problem and must depend on the judgment of clinicians and the resources available for extracting as much information as possible from the tissue obtained. 
Further study of the disease

Every new case of SSPE, whether seen in life or as an autopsy, is an opportunity to solve the problem of its aetiology and pathogenesis.

The history might provide information about previous exposure to wild measles virus or a live vaccine strain and whether other cases of SSPE have occurred in the same locale at about the same time. To prove that measles really is the cause of SSPE, and to discover what unfortunate combination of circumstances permits the disease to develop in rare individuals, we need urgently to isolate and culture the virus. Despite failure in a variety of inoculated animals and tissue culture system, these attempts should be repeated using standard techniques and others (as mentioned in Symposium, 1968) to free virus from host cells and antibody so that it can grow after inoculation. As the only tissue known to be affected in patients with SSPE is the central nervous system, attempts to isolate the virus in life require biopsy of the brain. The material obtained could also be used for other work. A search should be made for virus in systemic viscera, particularly organs of the reticulo-endothelial system and from blood and CSF in case there is a chronic, low grade viraemia. Until strains of virus have been isolated it will be difficult to study the factors causing persistence of infection and possibly entry of virus into a defective phase except by analogy with still largely unexplored animal and tissue culture models.

Morphological studies should be undertaken on suitable tissue samples to determine whether virus particles can be found and what are their physical forms and properties. Electron microscopy of negatively stained concentrates of homogenized tissues can be a particularly delicate and precise method for determining the probable identity of a virus, and it can be combined with immunological reactions for more specific identification of virions. Little is known still about the actual effects at the ultrastructural level of virus infection and multiplication on cells of the nervous system.

Immunology has an important role in studying SSPE. Classical techniques of assay applied to body fluids can show the evolution of the body's response to infection in terms of producing antibodies of various classes. Searches have been made, albeit unsuccessfully so far, for evidence of anti-brain antibodies and sensitized cells aroused by the infection and need to be repeated using more subtle techniques (Symposium, 1968). Despite the work of Kolar and his colleagues (Kolar, 1968) much has still to be learnt about the nature of the antibodies produced in SSPE, their source and the relative significance of $\gamma$-globulins produced systemically and within the CNS. Fluorescent antibody tests have revealed some of the features of measles antigens inside CNS cells, but more detailed examination is required of infected cells to determine their type and reaction to the infection and subsequent fate.

Lastly, biochemical studies might confirm at a different level much of the histological work showing damage to infected cells. It might also be used to study possible long-lasting metabolic perversions produced in surviving cells by the virus, and to examine possible factors involved in the temperate nature of the infection.

\section{Treatment}

Chemotherapy probably has little to offer so far owing to the lack of drugs effective against RNA viruses. Inconclusive trials have been made of compounds used for treating DNA virus infection (Freeman, 1968). Kolar et al. (1967) have reported remission of one case of SSPE after thymectomy, a treatment based on hypotheses about the autoimmune pathogenesis of tissue damage in SSPE.

Apart from these experimental approaches, symptomatic treatment and corticosteroids may help in the management of individual patients.

\section{Conclusion}

SSPE is an ingravescent disease probably due to measles virus acting in an ill-understood manner. Considered as a model for more typical slow-virus infections it should be possible to study the interactions of immunity, direct viral attack and disordered cell metabolism in a clinical situation, and to compare them with the reactions in multiple sclerosis in particular, for which there are now several reports of moderately high levels of anti-measles antibody in serum and CSF (Pette, 1968).

\section{Note added in proof}

Using mixed tissue cultures from a cortical biopsy from a child with SSPE, and a susceptible line of HeLa cells, Horta Barbosa and his co-workers (1969) have obtained direct evidence of measles virus, probably in an incomplete form, as the aetiological agent in this disease.

\section{Acknowledgments}

I am grateful to Dr M. A. Woodhouse for permission to reproduce Fig. 6 and to Mrs J. Almeida and Dr G. S. Graveson and Dr P. K. Robinson for their advice.

\section{References}

AdAms, J.H., BaIRD, C. \& Filloy, L. (1966) Inclusion bodies in measles encephalitis. J. Amer. med. Ass. 195, 290.

Adels, B.R., Gajdusek, D.C., Gibbs, C.J., Albrecht, P. \& Rogers, N.G. (1968) Attempts to transmit subacute sclerosing panencephalitis and isolate a measles related agent, with a study of the immune response in patients and experimental animals. Symposium, 1968, p. 30.

VAN BogaERT, L. (1945) La leucoencéphalite sclérosante subaigue. J. Neurol. Neurosurg. Psychiat. 8, 101.

vaN BogaERT. L. (1958) Encéphalites d'origine inconnue. 
Handb. Spez. Path. Anat. (Ed. by O. Lubarsch, F. Henke and R. Rössle). Springer Verlag, Berlin. 13/2A, 394.

Bouteille, M., Fontaine, C., Vedrenne, C. \& DelaRue, J. (1965) Sur un cas d'encéphalite subaigue à inclusions. Etude anatomo-clinique et ultrastructurale. Rev. neurol. 113, 454.

CANAL, N. \& ToRCK, P. (1964) An epidemiological study of subacute sclerosing leucoencephalitis in Belgium. J. neurol. Sci. 1, 380.

CовB, W. (1966) The periodic events of subacute sclerosing leucoencephalitis. Electroenceph. clin. Neurophysiol. 21, 278.

Cobb, W.A. \& Morgan Hughes, J.A. (1968) Non-fatal subacute sclerosing leucoencephalitis. J. Neurol. Neurosurg. Psychiat. 31, 115.

Connolly, J.H., Allen, I.V., Hurwitz, L.J. \& Millar J.H.D. (1967) Measles virus antibody and antigen in subacute sclerosing panencephalitis. Lancet, i, 542.

Cutler, R.W.P., Watters, G.V., Hammerstad, J.V.P. \& MERLER, E. (1967) Origin of cerebrospinal fluid gammaglobulin in subacute sclerosing leukoencephalitis. Arch. Neurol. (Chic.), 17, 620.

DAwson, J.R. (1933) Cellular inclusions in cerebral lesions of lethargic encephalitis. Amer. J. Path. 9, 7.

Dayan, A.D. \& Cumings, J.N. (1969) An infantile case of subacute sclerosing panencephalitis with an abnormal ganglioside pattern in the brain. Arch. Dis. Child. (In press).

Dayan, A.D., Gostling, J.V.T., Greaves, J.L., Stevens. D.W. \& Woodhouse, M.A. (1967) Evidence of pseudomyxovirus in the brain in subacute sclerosing leucoencephalitis. Lancet, i, 980.

ENDERS-RUCKLE, G. (1965) Methods of determining immunity duration and character of immunity resulting from measles. Arch. ges. Virusforsch. 16, 182.

Foley, J. \& Williams, D. (1953) Inclusion encephalitis and its relation to subacute sclerosing leucoencephalitis: a report of five cases. Quart. J. Med. 22 N.S., 157.

Frazer, K.B. (1967) Defective and delayed myxovirus infections. Brit. med. Bull. 23, 178.

FreEMAN, J.M. (1968) Treatment of subacute sclerosing panencephalitis with 5-bromo-2-deoxyuridine and pyran copolymer. Symposium, 1968, p. 176.

Freeman, J.M., Magoffin, R.J., Lennette, E.H. \& HernDON, R.M. (1967) Additional evidence of the relation between subacute inclusion-body encephalitis and measles virus. Lancet, ii, 129.

Gibbs, F.A., Gibbs, E.L., Carpenter, P.R. \& Spies, H.W. (1959) Electroencephalographic abnormality in 'uncomplicated' childhood diseases. J. Amer. med. Ass. 171, 1050. GREENFIELD, J.G. (1950) Encephalitis and encephalomyelitis in England and Wales during the last decade. Brain, 73,141.

GuazzI, G.C. (1961) The distribution of brain stem and medullary lesions in subacute sclerosing leucoencephalitis. Symposium, 1961, p. 470.

HeRndon, R.M. \& Rubinstein, L.J. (1968) Light and electron microscopy observations on the development of viral particles in the inclusions of Dawson's encephalitis (subacute sclerosing panencephalitis). Symposium, 1968, p. 8.

Horta Barbosa, L., Fuccillo, D.A., Sever, J.L. \& Zeman, W. (1969) Subacute sclerosing panencephalitis: isolation, of measles virus from a brain biopsy. Nature (Lond.), 221, 974.

KatZ, M., Rorke, L.B., Masland, W.S., Koprowski, H. \& TUCKER, S.H. (1968) Transmission of encephalitogenic agents from brains of patients with subacute sclerosing panencephalitis to ferrets. New Engl. J. Med. 279, 793.

KolAR, O. (1968) Immunopathologic aspects of subacute sclerosing panencephalitis. Symposium, 1968, p. 107.

Kolar, O., Obrucnik, M., Behounkova, L., Musil, J. \& Penickova, V. (1967) Thymectomy in subacute sclerosing leucoencephalitis. Brit. med. J. 2, 22.

Lancet (1968) Subacute problems. ii, 1177.
Ledeen, R., Salsman, K. \& Cabrera, M. (1968) Gangliosides in subacute sclerosing leukoencephalitis: isolation and fatty acid composition of nine fractions. J. Lipid Res. 9, 129.

LEGG, N.J. (1967) Virus antibodies in subacute sclerosing panencephalitis: a study of 22 patients. Brit. med. J. 3, 350.

Lennette, E.H., Magoffin, R.L. \& Freeman, J.M. (1968) Immunologic evidence of measles virus as an etiological agent in subacute sclerosing panencephalitis. Symposium, 1968 , p. 21.

LoRAND, B., NAGY, T. \& TARISKA, S. (1962) Subacute progressive panencephalitis. Wld Neurol. 3, 376.

Malamud, N., Haymaker, W. \& Pinkerton, H. (1950) Inclusion encephalitis, with a clinicopathological report of three cases. Amer. J. Path. 26, 133.

Metz, H., Gregoriou, H. \& Sandifer, P. (1964) Subacute sclerosing panencephalitis: a review of 17 cases with special'reference to clinical diagnostic criteria. Arch. Dis. Child. 39, 554.

OsetowsKa, E. (1961) The distribution of telencephalic lesions in subacute sclerosing leucoencephalitis. Symposium, 1961, p. 414.

OSETOWSKA, E. \& TORCK, P. (1962) Subacute sclerosing leucoencephalitis: analysis of complementary features. Wld Neurol. 2, 566.

Pampiglione, G. (1964a) Polymyographic studies of some involuntary movements in subacute sclerosing panencephalitis. Arch. Dis. Child. 39, 558.

Pampiglione, G. (1964b) Prodromal phase of measles: some neurophysiological studies. Brit. med. J. 2, 1296.

Pelc, S., PÉrier, J.O. \& Quersin-ThiRY, L. (1958) Resultats expérimentaux dans l'encéphalite humaine type encéphalite subaigue à inclusions, leucoencéphalite sclérosante subaigue. Rev. neurol. 98, 3.

Périer, O., Vanderhaeghen, J.J. \& Pelc, S. (1967) Subacute sclerosing leucoencephalitis: electron microscopic findings in two cases with inclusion bodies. Acta neuropathol. (Berl.), 8, 362.

PetTe, E. (1968) Measles virus: a causative agent in multiple sclerosis. Symposium, 1968, p. 168.

Pette, H. \& DöRING, G. (1939) Uber einheimische panencephalomyelitis vom charakter der encephalitis japonica. Dtsch. Z. Nervenheilk. 149, 7.

RADERmeCKer, J. (1949) Aspects électroencéphalographique dans trois cas d'encéphalite subaigue. Acta Neurol. Psychiat. Belg. 49, 222.

Rustigian, R. (1966) Persistent infection of cells in culture by measles virus. J. Bact. 92, 1792; 1805.

ScHNECK, S.A. (1968) Vaccination with measles and central nervous system disease. Symposium, 1968, p. 79.

Sherman, F.E., Davis, R.L. \& HAYMaKeR, W. (1961) Subacute inclusion encephalitis, Report of a case with observations on the fluorescent anti-herpes simplex antibody reaction. Acta neuropathol. (Berl.), 1, 271.

Symposium (1961) Encephalitides (Ed. by L. van Bogaert, J. Radermecker, J. Hozay and A. Lowenthal). Elsevier, Amsterdam.

Symposium (1968) Measles virus and subacute sclerosing panencephalitis. (Ed. by J. L. Sever and W. Zeman). Neurology (Minneap.), 18, No 1, Part 2

Tellez Nagel, I. \& HaRTer, D.H. (1966) Subacute sclerosing leucoencephalitis: ultrastructure of intranuclear and intra-cytoplasmic inclusions. Science, 154, 899.

Waterson, A.P. \& Almeida, J.D. (1966) Taxonomic implications of myxovirus. Nature (Lond.), 210, 1138.

WebB, H.E. \& SMITH, C.E.G. (1966) Relation of immune response to development of central nervous system lesions in virus infections of man. Brit. med. J. 2, 1179.

Zeman, W. \& Kolar, O. (1968) Reflections on the etiology and pathogenesis of subacute sclerosing panencephalitis. Symposium, 1968, p. 1. 